\title{
Resetting Process of Peripheral Circadian Gene Expression after the Combined Reversal of Feeding Schedule and Light/Dark Cycle Via a 24-h Light Period Transition in Rats
}

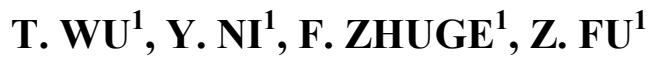 \\ ${ }^{1}$ College of Biological and Environmental Engineering, Zhejiang University of Technology, China
}

Received May 11, 2009

Accepted August 11, 2009

On-line November 20, 2009

\section{Summary}

To investigate the effect of light cue on the resetting of the peripheral clocks, we examined the resetting processes of clock genes (Per1, Per2, Bmal1, Cry1, Dec1, and Rev-erbo) in the liver and heart of rats after the feeding and light-dark (LD) reversal via a 24-h light period transition. The liver clock was reset quickly within 3 days, while the heart clock needed a longer time course of 5-7 days to be completely re-entrained. Moreover, the reentrainment of Per1 and Per2 in the liver clock was more rapid than that of the other four clock genes, suggesting the important role of these two clock genes in initiating the circadian resetting of the hepatic clock. However, the resetting rates of these two clock genes were as similar as the others in the heart clock. Therefore, the resetting mechanisms underlining these two peripheral clocks may be totally distinct. Furthermore, the reentrainment of the liver and heart clocks were relatively lengthened after the feeding and LD reversal via a light period transition compared to a dark period transition, suggesting a simultaneous shift of feeding schedule and the LD cycle may facilitate the circadian resetting in rats.

\section{Key words}

Light/dark reversal • Peripheral clocks • Liver • Heart

\section{Corresponding author}

Z. Fu, College of Biological and Environmental Engineering, Zhejiang University of Technology, No. 6 District, Zhaohui, Hangzhou, Zhejiang, 310032, China. Fax: 86-571-8832-0599.

E-mail: azwfu2003@yahoo.com.cn

\section{Introduction}

In mammals, the circadian rhythms in behavior and physiology are organized by a central pacemaker located in the suprachiasmatic nuclei (SCN) of the hypothalamus and suboscillators in peripheral tissues such as the liver, heart, etc. (Green et al. 2008). One of the essential features of the circadian clock is its entrainability to daily changes in the environment. The SCN clock is reset mainly by the light cue via the retinohypothalamic tract (Barrett and Takahashi 1995, Hastings 1997, Dunlap 1999), whereas the peripheral clocks seem to be reset mainly by the food cue in mammals (Damiola et al. 2000, Hara et al. 2001, Stokkan et al. 2001, Wakamatsu et al. 2001). To date, numerous studies have attempted to explain mechanisms of the light induced resetting of the SCN clock. For example, light pulses applied during the night lead to increased levels of Perl and Per 2 in the SCN that may be important to the light-induced circadian resetting of the SCN clock (Albrecht et al. 1997, Liu et al. 1997, Shigeyoshi et al. 1997). Moreover, Ishida et al. (2005) found that light could rapidly induce Perl expression in the adrenal gland via the SCN-sympathetic nervous system. However, the effect of light cue on the re-entrainment of the fooddominated peripheral clocks has not been fully discussed.

In previous studies on the light-induced circadian resetting, it was demonstrated that phase delays are accomplished more rapidly and with less disturbance than phase advances (Illnerová et al. 1987, Takamure et al. 1991, Miranda-Anaya et al. 2000, Reddy et al. 2002, Sujino et al. 2007). However, the discrepancy between 
the circadian resetting induced by photoperiod alteration via dark or light period transition has seldom been investigated. In the light-dominated pineal clock (Wu et al. 2008a), our recent studies indicated that the resetting processes of clock genes were noticeably lengthened after the light-dark (LD) reversal via a light period transition as compared with that via a dark period transition (Wu et al. 2009). Although the circadian phases of clock genes in other peripheral tissues are mainly dominated by food cues (Damiola et al. 2000, Hara et al. 2001, Stokkan et al. 2001, Wakamatsu et al. 2001), we also found that reversing the feeding schedule together with the LD cycle via a dark period transition markedly enhanced the feeding-induced resetting of peripheral clocks ( $\mathrm{Wu}$ et al. 2008b). Thus, we were interested to know whether the food-dominated resetting processes of clock genes in peripheral tissues would be different after the LD reversal via a light period transition as compared with that via a dark period transition in our previous studies $(\mathrm{Wu}$ et al. 2008b). To clarify this, we investigated the resetting processes of Per1 and Per2, as well as other clock genes (Bmal1, Cry1, Dec1, Rev-erb $\alpha$ ) in the liver and heart of rats after the reversal of feeding schedule and LD cycle via a 24-h light period transition.

\section{Methods}

\section{Animals and experimental design}

Male Wistar rats (body weight 90-100 g) were kept in our animal facilities (illumination with fluorescent strip lights of 200 lux at cage level; $22 \pm 1{ }^{\circ} \mathrm{C}$ ) under a $12 \mathrm{~h}: 12 \mathrm{~h}$ light-dark (LD) cycle. Water was available ad libitum, while food was provided only in the dark period. The onset of light was defined as Zeitgeber time 0 (ZT0), and the onset of darkness was ZT12.

To test the resetting processes of clock genes in the peripheries, rats were divided into two groups after their adaptation to the normal LD cycle. In the control group, rats were sacrificed at 4-h intervals of the daily cycle, starting at ZT0. In the resetting group, rats were starved for two days and then subjected to the reversal conditions for both feeding schedule and LD cycle by extending the light period for $24 \mathrm{~h}$. Rats in this group were sampled every $4 \mathrm{~h}$ from the start of the phase change on the 1 st day (Time 0-24 h), the 3rd day (Time 48-72 h), the 5th day (Time 96-120 h), and the 7th day (Time 144-168 h). The purpose of fasting was to stimulate the rats to consume food immediately after the food phase shift, allowing the information of food stimuli to be transmitted immediately as the feeding schedule changes. We have confirmed that fasting for 2 days did not alter the expression of circadian genes in the liver and heart (Dong et al. 2009).

All rats were killed after deep anesthesia by an i.p. injection of pentobarbital sodium. Livers and hearts were quickly removed, immediately frozen on dry ice and kept at $-80{ }^{\circ} \mathrm{C}$. During the dark phase, the dissection was carried out under dim red light. Every effort was made to minimize animal suffering and the number of rats required for each experiment. All animal care and use procedures were in accordance with guidelines of the Research Committee of Zhejiang University of Technology.

\section{$R N A$ isolation and reverse transcription}

The total RNA from livers and hearts was isolated using the TRIzol reagent (Invitrogen, Carlsbad, CA) according to the manufacturer's instructions with some modifications as previously described (Wu et al. 2008b).

\section{Real-time PCR}

Quantitative real time PCR was performed using the SYBR ${ }^{\circledR}$ ExScript $^{\mathrm{TM}}$ PCR Kit (Takara Biochemicals, China) in a total volume of $10 \mu \mathrm{l}$. The primer sequences for Per1, Per2, Bmall, Cry1, Decl were the same as in our previous report (Wu et al. 2008a). The primer sequences for Rev-erb $\alpha$ were as follows: Forward, ACAGCTGACACCACCCAGATC; Reverse, CATGGG CATAGGTGAAGATTTCT. PCR amplification and quantification were performed in a real-time PCR system (ABI-7300, USA) as follows: denaturation for $10 \mathrm{~s}$ at $95{ }^{\circ} \mathrm{C}$, followed by 40 cycles of $5 \mathrm{~s}$ at $95{ }^{\circ} \mathrm{C}, 31 \mathrm{~s}$ at $60{ }^{\circ} \mathrm{C}$. The relative quantification of gene expression was analyzed from the measured threshold cycles $\left(\mathrm{C}_{\mathrm{t}}\right)$ by using the $2^{-\Delta \Delta \mathrm{Ct}}$ method (Livak and Schmittgen 2001). The data were normalized to the amount of glyceraldehyde-3-phosphate dehydrogenase (GAPDH).

\section{Data analysis}

All data are given as the mean \pm S.E.M. of four animals. The values for the mRNA levels are presented as relative values in all experiments. The daily oscillation of each circadian gene was analyzed by one-way ANOVA. The effect of group on the expression pattern of each gene was tested by two-way ANOVA. When a significant difference was observed by using two-way ANOVA, the difference at each time-point was analyzed by the 
Student-Newman-Keuls test, and was considered statistically significant at $\mathrm{p}<0.05$. Moreover, we estimated the peak phase of each cycling gene from the peak time of the most highly correlated cosine wave (Cosine Wave Analysis). The mRNA levels were fitted in Matlab 7.0.1 program by a nonlinear least-squares regression with the following cosine-wave equation (cosinor): $\mathrm{y}=[\mathrm{A}+\mathrm{B} \times \cos (2 \pi \times(\mathrm{T}-\mathrm{C}) / 24)]$ where $\mathrm{y}$ represented the level of mRNA, A was the mean level of mRNA, B was the amplitude of mRNA oscillation, $C$ was the acrophase of mRNA oscillation, and $\mathrm{T}$ was the time (h). The peak time was considered when the mRNA level at a given time-point was within $95 \%$ confidence bounds of the expected acrophase. The value $\mathrm{R}^{2}$ quantified significance of the fit. Statistical significance of the cosine fit was considered when $\mathrm{F}$ was greater than $\mathrm{F}_{0.05}$.

\section{Results}

Resetting processes of clock genes in the liver after the reversal of feeding schedule and light-dark cycle via a 24-h light period transition

To determine the effect of the LD reversal on the feeding-induced resetting of clock genes in the liver, we first examined the 24-h expression patterns of clock genes (Per1, Per2, Bmal1, Cry1, Dec1, Rev-erb $\alpha$ ) in the control condition, and then in the $1 \mathrm{st}, 3 \mathrm{rd}$, and 5 th days after the LD reversal via a 24-h light period transition (Fig. 1). Expression profiles of all selected clock genes exhibited a clear daily rhythmicity in the liver of the control rats (Table 1, $\mathrm{p}<0.05$; Table 2, $\mathrm{F}>\mathrm{F}_{0.05}$ ). After the reversal of feeding schedule and $\mathrm{LD}$ cycle, we compared the expression profiles of all selected genes using twoway ANOVA tests for the effect of group, time and their interaction (Table 1), which revealed a group $\times$ time interaction for all examined genes in every resetting days except for Bmall in day 1. Per1 and Per2 displayed a rapid phase-shift rate (Table 2 ). In day 1 , these two clock genes did not display a significant circadian rhythm, respectively (Table $2, \mathrm{~F}<\mathrm{F}_{0.05}$ ). In day 3 , the peak phases of both two clock genes were shifted $12 \mathrm{~h}$, and the newly established peak phases was well maintained on day 5 (Table 2). The resetting processes of other four clock genes were prolonged compared to that of Perl and Per2 (Table 2). In day 1, Bmall, Cryl, and Decl showed a small peak phase shift that was not more than $4 \mathrm{~h}$, while Rev-erb $\alpha$ did not display any significant circadian rhythm (Table 2, $\mathrm{F}<\mathrm{F}_{0.05}$ ). Then, larger phase shift was displayed for each clock gene in day 3 (Table 2). Finally, the circadian phases of these four clock genes were totally reversed on day 5 (Table 2).

Table 1. Interaction between group and time on clock gene transcription in the liver after the reversal of feeding schedule and LD cycle.

\begin{tabular}{|c|c|c|c|c|}
\hline Gene & Days & Group & Time & Group $\times$ Time \\
\hline \multirow[t]{3}{*}{ Perl } & Day 1 & $\mathrm{~F}=1.024 ; \mathrm{p}=0.317$ & $\mathrm{~F}=19.064 ; \mathrm{p}<0.001$ & $\mathrm{~F}=7.940 ; \mathrm{p}<0.001$ \\
\hline & Day 3 & $\mathrm{~F}=24.372 ; \mathrm{p}<0.001$ & $\mathrm{~F}=8.008 ; \mathrm{p}<0.001$ & $\mathrm{~F}=20.119 ; \mathrm{p}<0.001$ \\
\hline & Day 5 & $\mathrm{~F}=89.279 ; \mathrm{p}<0.001$ & $\mathrm{~F}=11.561 ; \mathrm{p}<0.001$ & $\mathrm{~F}=29.344 ; \mathrm{p}<0.001$ \\
\hline \multirow[t]{3}{*}{ Per2 } & Day 1 & $\mathrm{~F}=14.274 ; \mathrm{p}<0.001$ & $\mathrm{~F}=19.923 ; \mathrm{p}<0.001$ & $\mathrm{~F}=5.380 ; \mathrm{p}<0.001$ \\
\hline & Day 3 & $F=106.977 ; p<0.001$ & $\mathrm{~F}=16.554 ; \mathrm{p}<0.001$ & $\mathrm{~F}=43.136 ; \mathrm{p}<0.001$ \\
\hline & Day 5 & $\mathrm{~F}=0.101 ; \mathrm{p}=0.752$ & $\mathrm{~F}=2.683 ; \mathrm{p}=0.027$ & $\mathrm{~F}=20.916 ; \mathrm{p}<0.001$ \\
\hline \multirow[t]{3}{*}{$R e v-e r b \alpha$} & Day 1 & $\mathrm{~F}=0.846 ; \mathrm{p}=0.363$ & $\mathrm{~F}=29.171 ; \mathrm{p}<0.001$ & $\mathrm{~F}=8.039 ; \mathrm{p}<0.001$ \\
\hline & Day 3 & $\mathrm{~F}=0.632 ; \mathrm{p}=0.432$ & $\mathrm{~F}=7.522 ; \mathrm{p}<0.001$ & $\mathrm{~F}=22.852 ; \mathrm{p}<0.001$ \\
\hline & Day 5 & $\mathrm{~F}=7.549 ; \mathrm{p}=0.009$ & $\mathrm{~F}=4.365 ; \mathrm{p}=0.002$ & $F=26.653 ; p<0.001$ \\
\hline \multirow[t]{3}{*}{ Bmal1 } & Day 1 & $\mathrm{~F}=18.290 ; \mathrm{p}<0.001$ & $\mathrm{~F}=65.358 ; \mathrm{p}<0.001$ & $\mathrm{~F}=1.373 ; \mathrm{p}=0.249$ \\
\hline & Day 3 & $\mathrm{~F}=2.013 ; \mathrm{p}=0.164$ & $\mathrm{~F}=21.401 ; \mathrm{p}<0.001$ & $\mathrm{~F}=24.840 ; \mathrm{p}<0.001$ \\
\hline & Day 5 & $\mathrm{~F}=13.778 ; \mathrm{p}=0.001$ & $\mathrm{~F}=6.540 ; \mathrm{p}<0.001$ & $\mathrm{~F}=53.125 ; \mathrm{p}<0.001$ \\
\hline \multirow[t]{3}{*}{ Cryl } & Day 1 & $\mathrm{~F}=3.761 ; \mathrm{p}=0.061$ & $\mathrm{~F}=47.346 ; \mathrm{p}<0.001$ & $\mathrm{~F}=6.507 ; \mathrm{p}<0.001$ \\
\hline & Day 3 & $\mathrm{~F}=0.112 ; \mathrm{p}=0.740$ & $\mathrm{~F}=8.466 ; \mathrm{p}<0.001$ & $\mathrm{~F}=40.141 ; \mathrm{p}<0.001$ \\
\hline & Day 5 & $\mathrm{~F}=6.813 ; \mathrm{p}=0.013$ & $\mathrm{~F}=3.014 ; \mathrm{p}=0.017$ & $\mathrm{~F}=24.806 ; \mathrm{p}<0.001$ \\
\hline \multirow[t]{3}{*}{ Decl } & Day 1 & $\mathrm{~F}=4.628 ; \mathrm{p}=0.038$ & $\mathrm{~F}=10.355 ; \mathrm{p}<0.001$ & $\mathrm{~F}=3.152 ; \mathrm{p}=0.013$ \\
\hline & Day 3 & $\mathrm{~F}=2.410 ; \mathrm{p}=0.129$ & $\mathrm{~F}=2.818 ; \mathrm{p}=0.022$ & $\mathrm{~F}=9.263 ; \mathrm{p}<0.001$ \\
\hline & Day 5 & $\mathrm{~F}=0.229 ; \mathrm{p}=0.635$ & $\mathrm{~F}=2.426 ; \mathrm{p}=0.044$ & $F=21.057 ; p<0.001$ \\
\hline
\end{tabular}




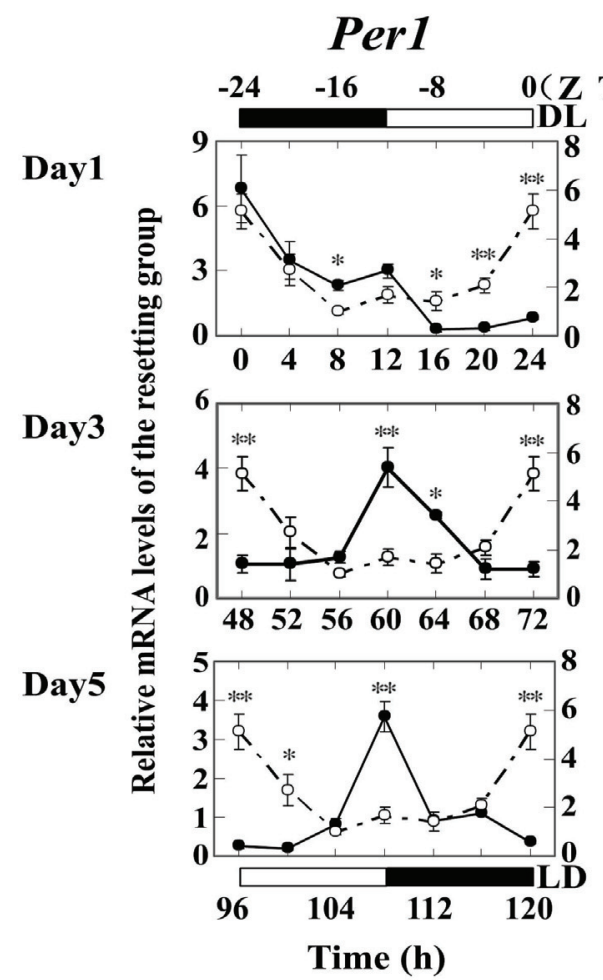

Bmal1
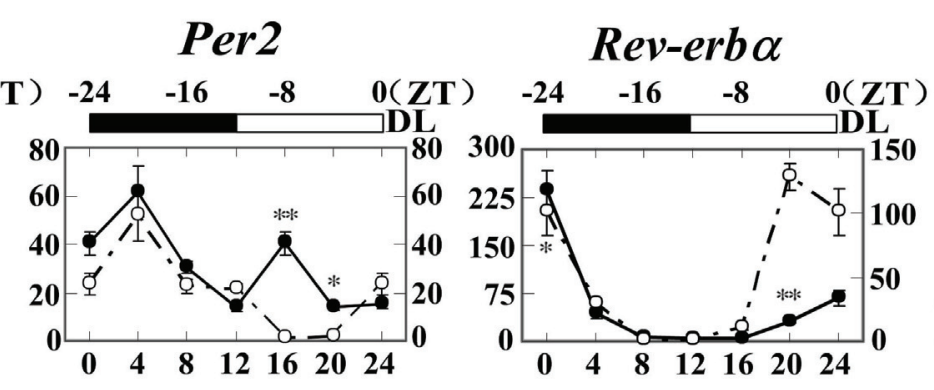

Rev-erb $\alpha$
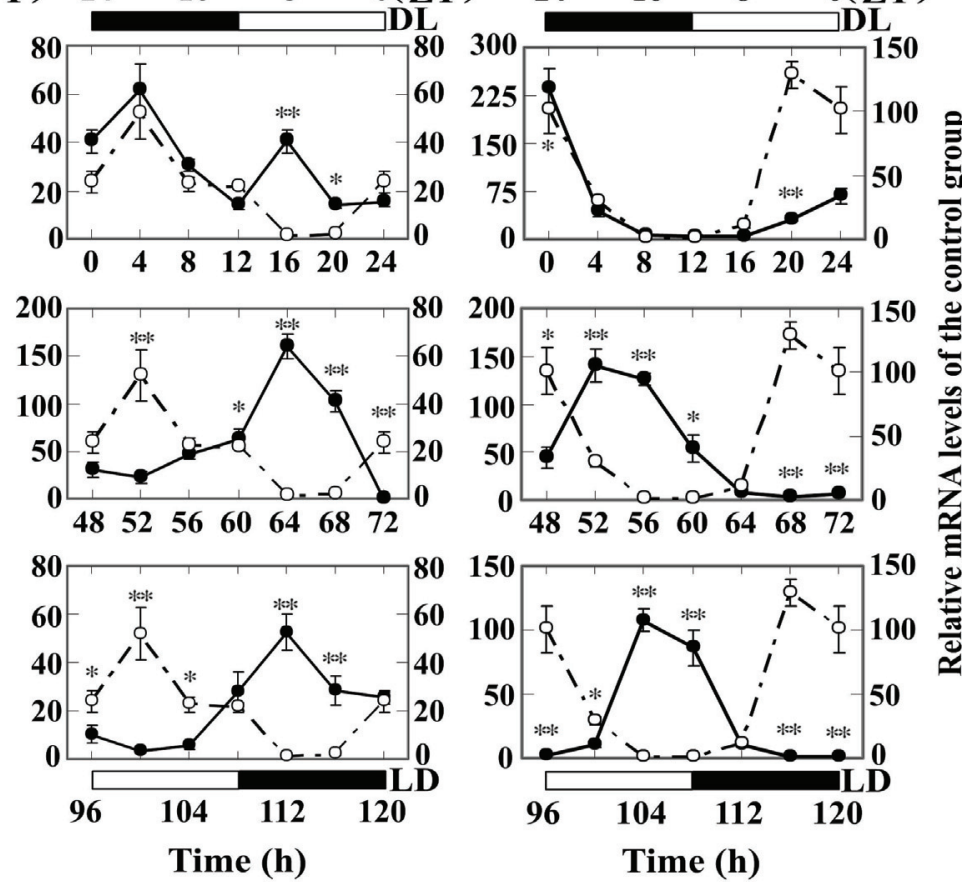

Dec1

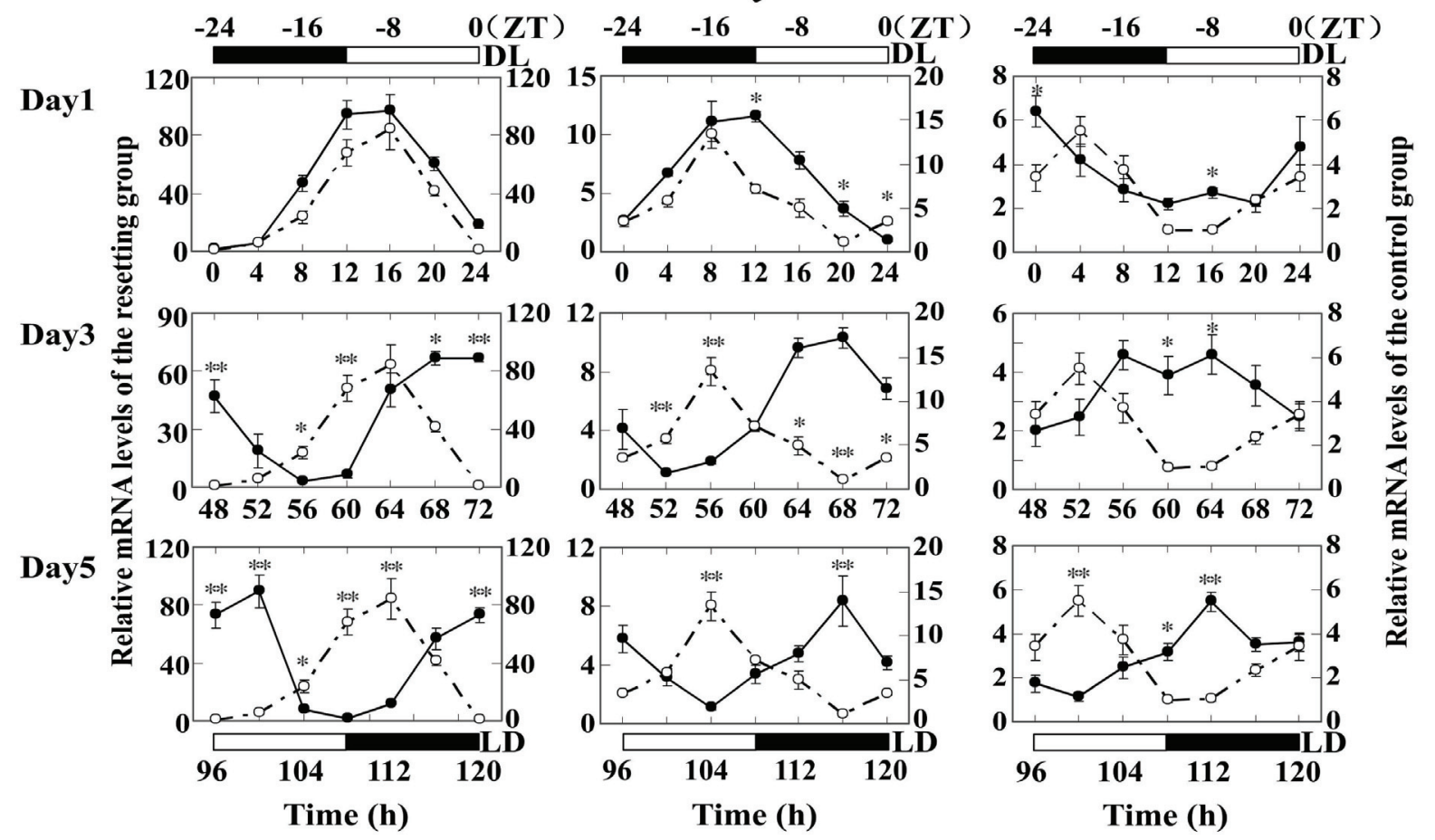

Fig. 1. Resetting processes of clock genes in the liver after the reversal of feeding schedule and light-dark cycle via a $24-\mathrm{h}$ light period transition. Expression profiles of clock genes were examined in the liver of rats under the control condition and days after the feeding and LD reversal. Full dots/solid lines represent data for the resetting group, and open circles/dashed lines indicate data for the control group. The values on the left side of each panel show the corresponding mRNA levels in the resetting group, while the values on the right side of each panel show the corresponding mRNA levels in the control group (the ZT24 value represents a replotting of the ZTO value). The black bars on the top of each column represent the duration of the dark phase in the control group, whereas the black bars on the bottom of each column represent the duration of the dark phase in the resetting group. The quantitative representations of multiple results are expressed as values relative to the minimum value of the control group in LD condition. Each value represents the mean \pm S.E.M. of four animals $(* p<0.05 ; * * p<0.01)$. 
Table 2. Cosine Wave Analysis of circadian gene expression in the liver clock.

\begin{tabular}{|c|c|c|c|c|c|}
\hline Gene & Days & Acrophase time & $\mathbf{F} / \mathbf{F}_{0.05}$ & $\mathbf{R}^{2}$ & Phase shift \\
\hline \multirow[t]{4}{*}{ Perl } & Control & ZT0 & $12.86 / 6.61^{*}$ & 0.72 & $0 \mathrm{~h}$ \\
\hline & Day 1 & $\mathrm{~ns}$ & $1.84 / 6.61$ & 0.27 & $\mathrm{~ns}$ \\
\hline & Day 3 & ZT12 & $12.36 / 6.61^{*}$ & 0.71 & $12 \mathrm{~h}$ \\
\hline & Day 5 & ZT12 & $6.97 / 6.61^{*}$ & 0.58 & $12 \mathrm{~h}$ \\
\hline \multirow[t]{4}{*}{ Per2 } & Control & $\mathrm{ZT} 4$ & $19.51 / 6.61^{*}$ & 0.80 & $0 \mathrm{~h}$ \\
\hline & Day 1 & $\mathrm{~ns}$ & $1.32 / 6.61$ & 0.21 & $\mathrm{~ns}$ \\
\hline & Day 3 & ZT16 & $18.39 / 6.61^{*}$ & 0.79 & $12 \mathrm{~h}$ \\
\hline & Day 5 & ZT16 & $25.95 / 6.61^{*}$ & 0.84 & $12 \mathrm{~h}$ \\
\hline \multirow[t]{4}{*}{ Rev-erb $\alpha$} & Control & ZT0 & $50.20 / 6.61^{*}$ & 0.91 & $0 \mathrm{~h}$ \\
\hline & Day 1 & $\mathrm{~ns}$ & $4.55 / 6.61$ & 0.48 & $\mathrm{~ns}$ \\
\hline & Day 3 & ZT8 & $31.03 / 6.61^{*}$ & 0.86 & $8 \mathrm{~h}$ \\
\hline & Day 5 & ZT12 & $21.96 / 6.61^{*}$ & 0.81 & $12 \mathrm{~h}$ \\
\hline \multirow[t]{4}{*}{ Bmall } & Control & ZT16 & $174.03 / 6.61^{*}$ & 0.97 & $0 \mathrm{~h}$ \\
\hline & Day 1 & ZT12 ZT16 & $338.18 / 6.61^{*}$ & 0.99 & $0 \sim 4 \mathrm{~h}$ \\
\hline & Day 3 & ZT20 & $79.69 / 6.61^{*}$ & 0.94 & $4 \mathrm{~h}$ \\
\hline & Day 5 & $\mathrm{ZT} 4$ & $36.77 / 6.61^{*}$ & 0.88 & $12 \mathrm{~h}$ \\
\hline \multirow[t]{4}{*}{ Cryl } & Control & ZT8 & $24.77 / 6.61 *$ & 0.83 & $0 \mathrm{~h}$ \\
\hline & Day 1 & ZT8 ZT12 & $199.53 / 6.61^{*}$ & 0.98 & $0 \sim 4 \mathrm{~h}$ \\
\hline & Day 3 & ZT16 ZT20 & $63.65 / 6.61^{*}$ & 0.93 & $8 \sim 12 \mathrm{~h}$ \\
\hline & Day 5 & ZT20 & $25.71 / 6.61^{*}$ & 0.84 & $12 \mathrm{~h}$ \\
\hline \multirow[t]{4}{*}{ Decl } & Control & $\mathrm{ZT} 4$ & $39.59 / 6.61 *$ & 0.89 & $0 \mathrm{~h}$ \\
\hline & Day 1 & ZT0 & $9.95 / 6.61 *$ & 0.67 & $4 \mathrm{~h}$ \\
\hline & Day 3 & ZT12 ZT16 & $16.93 / 6.61^{*}$ & 0.77 & $8 \sim 12 \mathrm{~h}$ \\
\hline & Day 5 & ZT16 & $13.38 / 6.61^{*}$ & 0.73 & $12 \mathrm{~h}$ \\
\hline
\end{tabular}

* Statistical significance of the cosine fit was considered when $F$ was more than $F_{0.05}\left(F>F_{0.05}\right)$. Acrophase time was considered when the mRNA level at a given time-point was within $95 \%$ confidence bounds of the acrophase. The value $R^{2}$ quantified significance of the fit. Phase shift was the time lag between the acrophase time in the control condition and that in resetting days; ns, no significant 24-h rhythm.

Resetting processes of clock genes in the heart after the reversal of feeding schedule and light-dark cycle via a 24-h light period transition

In comparison to the liver clock, we then monitored the expression profiles of Per1 and Per2 as well as other clock genes (Bmall, Cryl, Decl, Rev-erbo) in the heart on the same selected days as described above (Fig. 2). Expression profiles of these clock genes also exhibited a clear daily rhythmicity in the heart of the control rats (Table 3, $\mathrm{p}<0.05$; Table 4, $\mathrm{F}>\mathrm{F}_{0.05}$ ). After the reversal of feeding schedule and LD cycle, we compared the expression profiles of these genes using two-way ANOVA tests for the effect of group, time and their interaction (Table 3), which revealed a group $\times$ time interaction for all examined genes in every resetting days. As for Per 1 and Per2, the resetting processes of these two clock genes were prolonged in the heart compared to that in the liver. The 12-h peak phase shift of Per1 and Per2 was not accomplished until day 5 (Table 4). The established peak phases of Per 1 and Per 2 in day 5 were maintained in day 7 (Table 4). With regard to the other examined clock genes (Bmall, Cryl, Decl, Rev-erb $\alpha$ ), 5-7 days were needed to completely reverse the circadian phases of these clock genes in the heart (Table 4). Moreover, the resetting course was also characterized with gene-specific phase shift rates that were distinct to that in the liver. Bmall, Decl, and Rev-erb $\alpha$ displayed a relatively rapid phase shift rate by completing the resetting of their circadian phases within 5 days, while the circadian phase of $C r y l$ was not completely reset until day 7 (Table 4). 


\section{Heart}

Per1

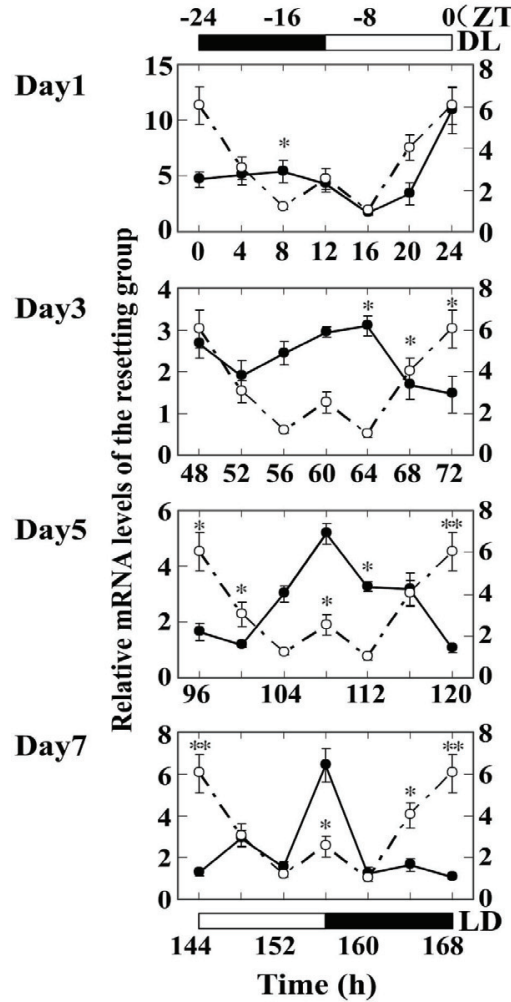

Bmal1

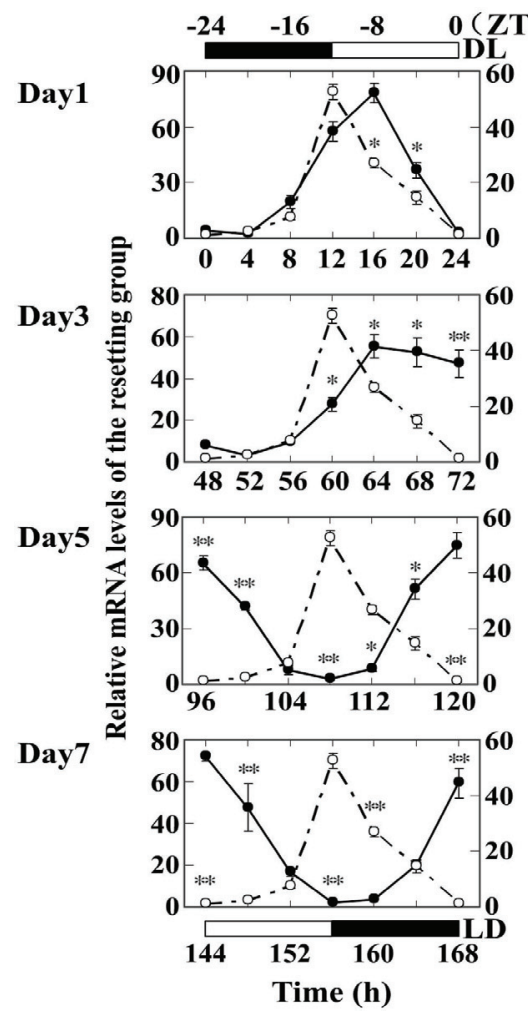

$-a-$ Control $\rightarrow$ Restting

Per2
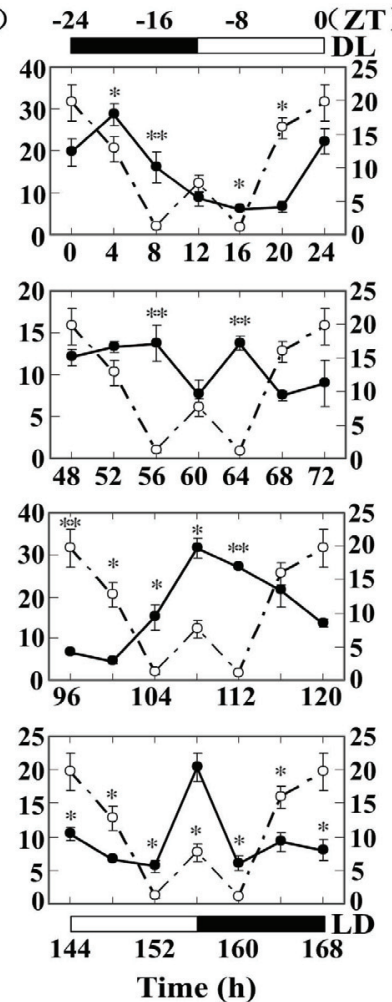

Cry1
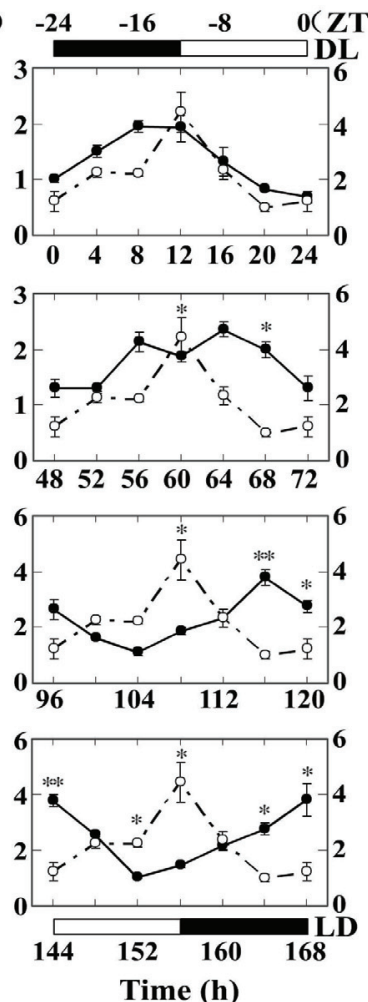

Rev-erb $\alpha$

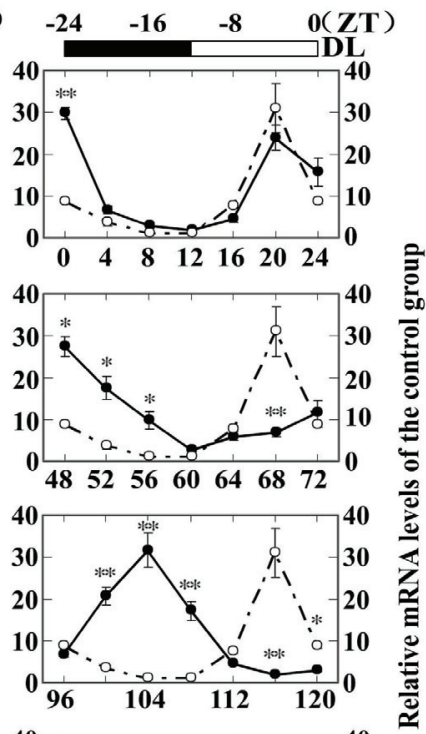

\section{Dec1}
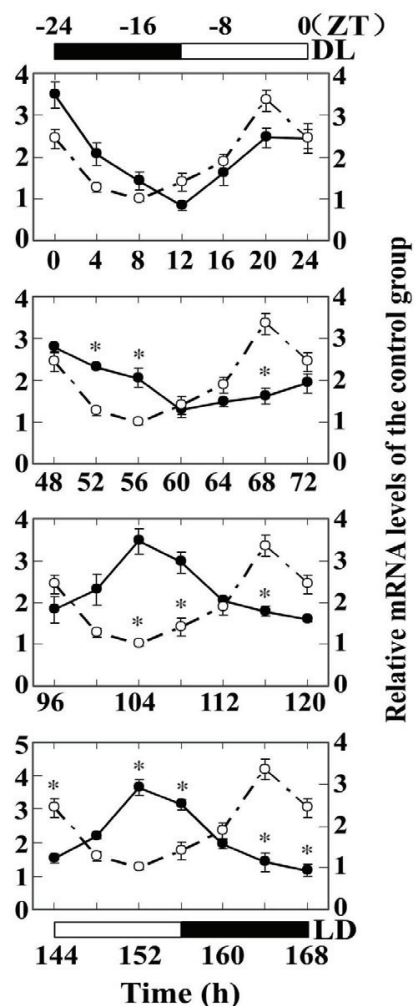

Fig. 2. Resetting processes of clock genes in the heart after the reversal of feeding schedule and light-dark cycle via a 24-h light period transition. Expression profiles of clock genes were examined in the heart of rats in the control condition and days after the feeding and LD reversal. For the explanation of each symbol see the legend of Figure 1. The quantitative representations of multiple results are expressed as values relative to the minimum value of the control group in LD condition. Each value represents the mean \pm S.E.M. of four animals $(* p<0.05 ; * * p<0.01)$. 
Table 3. Interaction between group and time on clock gene transcription in the heart after the reversal of feeding schedule and LD cycle.

\begin{tabular}{|c|c|c|c|c|}
\hline Gene & Days & Group & Time & Group $\times$ Time \\
\hline \multirow[t]{4}{*}{ Perl } & Day 1 & $\mathrm{~F}=11.661 ; \mathrm{p}=0.002$ & $\mathrm{~F}=11.841 ; \mathrm{p}<0.001$ & $\mathrm{~F}=3.312 ; \mathrm{p}=0.010$ \\
\hline & Day 3 & $\mathrm{~F}=15.487 ; \mathrm{p}<0.001$ & $\mathrm{~F}=5.761 ; \mathrm{p}=0.001$ & $\mathrm{~F}=11.151 ; \mathrm{p}<0.001$ \\
\hline & Day 5 & $\mathrm{~F}=8.036 ; \mathrm{p}=0.007$ & $\mathrm{~F}=5.835 ; \mathrm{p}<0.001$ & $\mathrm{~F}=19.904 ; \mathrm{p}<0.001$ \\
\hline & Day 7 & $\mathrm{~F}=12.453 ; \mathrm{p}=0.001$ & $\mathrm{~F}=4.649 ; \mathrm{p}=0.001$ & $\mathrm{~F}=7.481 ; \mathrm{p}<0.001$ \\
\hline \multirow[t]{4}{*}{ Per2 } & Day 1 & $\mathrm{~F}=12.801 ; \mathrm{p}=0.001$ & $\mathrm{~F}=20.065 ; \mathrm{p}<0.001$ & $\mathrm{~F}=8.211 ; \mathrm{p}<0.001$ \\
\hline & Day 3 & $\mathrm{~F}=0.018 ; \mathrm{p}=0.893$ & $\mathrm{~F}=8.497 ; \mathrm{p}<0.001$ & $\mathrm{~F}=16.055 ; \mathrm{p}<0.001$ \\
\hline & Day 5 & $\mathrm{~F}=33.516 ; \mathrm{p}<0.001$ & $\mathrm{~F}=11.003 ; \mathrm{p}<0.001$ & $\mathrm{~F}=32.971 ; \mathrm{p}<0.001$ \\
\hline & Day 7 & $\mathrm{~F}=3.538 ; \mathrm{p}=0.067$ & $\mathrm{~F}=19.496 ; \mathrm{p}<0.001$ & $\mathrm{~F}=15.140 ; \mathrm{p}<0.001$ \\
\hline \multirow[t]{4}{*}{$R e v-e r b \alpha$} & Day 1 & $F=7.973 ; p=0.007$ & $\mathrm{~F}=39.210 ; \mathrm{p}<0.001$ & $\mathrm{~F}=8.573 ; \mathrm{p}<0.001$ \\
\hline & Day 3 & $\mathrm{~F}=5.779 ; \mathrm{p}=0.021$ & $\mathrm{~F}=16.465 ; \mathrm{p}<0.001$ & $\mathrm{~F}=20.575 ; \mathrm{p}<0.001$ \\
\hline & Day 5 & $\mathrm{~F}=9.111 ; \mathrm{p}=0.004$ & $\mathrm{~F}=9.315 ; \mathrm{p}<0.001$ & $\mathrm{~F}=43.105 ; \mathrm{p}<0.001$ \\
\hline & Day 7 & $\mathrm{~F}=1.884 ; \mathrm{p}=0.178$ & $\mathrm{~F}=10.450 ; \mathrm{p}<0.001$ & $\mathrm{~F}=38.923 ; \mathrm{p}<0.001$ \\
\hline \multirow[t]{4}{*}{ Bmall } & Day 1 & $\mathrm{~F}=100.491 ; \mathrm{p}<0.001$ & $\mathrm{~F}=157.902 ; \mathrm{p}<0.001$ & $\mathrm{~F}=23.944 ; \mathrm{p}<0.001$ \\
\hline & Day 3 & $\mathrm{~F}=65.152 ; \mathrm{p}<0.001$ & $\mathrm{~F}=54.631 ; \mathrm{p}<0.001$ & $\mathrm{~F}=29.756 ; \mathrm{p}<0.001$ \\
\hline & Day 5 & $\mathrm{~F}=180.761 ; \mathrm{p}<0.001$ & $\mathrm{~F}=26.836 ; \mathrm{p}<0.001$ & $\mathrm{~F}=122.038 ; \mathrm{p}<0.001$ \\
\hline & Day 7 & $\mathrm{~F}=64.953 ; \mathrm{p}<0.001$ & $\mathrm{~F}=10.264 ; \mathrm{p}<0.001$ & $\mathrm{~F}=65.270 ; \mathrm{p}<0.001$ \\
\hline \multirow[t]{4}{*}{ Cryl } & Day 1 & $\mathrm{~F}=28.279 ; \mathrm{p}<0.001$ & $\mathrm{~F}=17.434 ; \mathrm{p}<0.001$ & $\mathrm{~F}=4.414 ; \mathrm{p}=0.002$ \\
\hline & Day 3 & $\mathrm{~F}=5.490 ; \mathrm{p}=0.024$ & $\mathrm{~F}=12.363 ; \mathrm{p}<0.001$ & $\mathrm{~F}=8.444 ; \mathrm{p}<0.001$ \\
\hline & Day 5 & $F=1.750 ; p=0.193$ & $\mathrm{~F}=5.739 ; \mathrm{p}<0.001$ & $\mathrm{~F}=20.072 ; \mathrm{p}<0.001$ \\
\hline & Day 7 & $\mathrm{~F}=5.974 ; \mathrm{p}=0.019$ & $\mathrm{~F}=4.127 ; \mathrm{p}=0.003$ & $\mathrm{~F}=21.860 ; \mathrm{p}<0.001$ \\
\hline \multirow[t]{4}{*}{ Decl } & Day 1 & $\mathrm{~F}=0.444 ; \mathrm{p}=0.509$ & $\mathrm{~F}=22.759 ; \mathrm{p}<0.001$ & $\mathrm{~F}=4.976 ; \mathrm{p}=0.001$ \\
\hline & Day 3 & $\mathrm{~F}=0.210 ; \mathrm{p}=0.649$ & $\mathrm{~F}=14.500 ; \mathrm{p}<0.001$ & $\mathrm{~F}=14.852 ; \mathrm{p}<0.001$ \\
\hline & Day 5 & $\mathrm{~F}=7.581 ; \mathrm{p}=0.009$ & $\mathrm{~F}=2.645 ; \mathrm{p}=0.029$ & $\mathrm{~F}=22.743 ; \mathrm{p}<0.001$ \\
\hline & Day 7 & $\mathrm{~F}=3.274 ; \mathrm{p}=0.078$ & $\mathrm{~F}=4.012 ; \mathrm{p}=0.003$ & $\mathrm{~F}=40.155 ; \mathrm{p}<0.001$ \\
\hline
\end{tabular}

\section{Discussion}

In the present study, we found that an abrupt 12-h phase shift of feeding schedule and LD cycle entrains the peripheral clocks with gene- and tissuespecific circadian resetting properties. The examined clock genes (Per1, Per2, Bmall, Cryl, Decl, and Rev-erb $\alpha$ ) finished their re-entrainment within 3-5 days in the liver, while their resetting courses took 5-7 days in the heart. Therefore, the circadian resetting proceeds faster in the liver than in the heart after the 12-h phase shift of feeding schedule and LD cycle, which is in accordance with the previous studies on the feedinginduced circadian resetting of peripheral clocks (Damiola et al. 2000, Wu et al. 2008b). The food cue is a principal timing cue for peripheral clocks, which can directly stimulate the liver clock rather than the heart clock. While the light-dark cycle can only indirectly entrain the circadian rhythm of the peripheral clocks. Therefore, the differential resetting rates of the liver and heart clocks may be mainly induced by the feeding stimulus. In addition, our recent studies reported that the resetting processes of Bmall, Cryl, Perl, and Decl after the same 12-h phase shift of LD cycle and feeding schedule via a 24-h light period transition were completed within 7-9 days in the rat pineal gland ( $\mathrm{Wu}$ et al. 2009). Thus, the circadian clock system displayed differential resetting rates of peripheral clocks after the 12-h phase shift of feeding schedule and LD cycle. Further understanding of the discrepancy of circadian resetting in multiple peripheral clocks may provide new knowledge to the molecular mechanism of jet lag.

The examined clock genes also displayed dissimilar resetting sequences between the liver and heart clocks. Since the resetting of circadian clocks to external time cues is initiated with rapid response of clock components, identification of resetting sequences of clock genes may be useful to explore the specific roles of 
Table 4. Cosine Wave Analysis of circadian gene expression in the heart clock.

\begin{tabular}{|c|c|c|c|c|c|}
\hline Gene & Days & Acrophase time & $F / F_{0.05}$ & $\mathbf{R}^{2}$ & Phase shift \\
\hline \multirow[t]{5}{*}{ Perl } & Control & ZT0 & $14.63 / 6.61^{*}$ & 0.75 & $0 \mathrm{~h}$ \\
\hline & Day 1 & $\mathrm{~ns}$ & $3.36 / 6.61$ & 0.40 & $\mathrm{~ns}$ \\
\hline & Day 3 & ns & $4.84 / 6.61$ & 0.49 & ns \\
\hline & Day 5 & ZT12 & $20.73 / 6.61^{*}$ & 0.84 & $12 \mathrm{~h}$ \\
\hline & Day 7 & ZT12 & $150.48 / 6.61^{*}$ & 0.97 & $12 \mathrm{~h}$ \\
\hline \multirow[t]{5}{*}{ Per 2} & Control & ZT0 & $17.51 / 6.61^{*}$ & 0.78 & $0 \mathrm{~h}$ \\
\hline & Day 1 & ZT4 & $52.09 / 6.61^{*}$ & 0.91 & $4 \mathrm{~h}$ \\
\hline & Day 3 & $\mathrm{~ns}$ & $1.12 / 6.61$ & 0.18 & ns \\
\hline & Day 5 & ZT12 & $36.77 / 6.61 *$ & 0.88 & $12 \mathrm{~h}$ \\
\hline & Day 7 & ZT12 & $32.8 / 6.61^{*}$ & 0.87 & $12 \mathrm{~h}$ \\
\hline \multirow[t]{5}{*}{ Rev-erb $\alpha$} & Control & ZT20 & $8.14 / 6.61^{*}$ & 0.62 & $0 \mathrm{~h}$ \\
\hline & Day 1 & ZT20 ZT24 & $16.30 / 6.61^{*}$ & 0.77 & $0 \sim 4 \mathrm{~h}$ \\
\hline & Day 3 & ZT0 ZT4 & $9.11 / 6.61^{*}$ & 0.65 & $4 \sim 8 \mathrm{~h}$ \\
\hline & Day 5 & ZT8 & $75.93 / 6.61^{*}$ & 0.94 & $12 \mathrm{~h}$ \\
\hline & Day 7 & ZT8 & $27.62 / 6.61^{*}$ & 0.85 & $12 \mathrm{~h}$ \\
\hline \multirow[t]{5}{*}{ Bmall } & Control & ZT12 & $17.53 / 6.61^{*}$ & 0.78 & $0 \mathrm{~h}$ \\
\hline & Day 1 & ZT12 ZT16 & $154.07 / 6.61^{*}$ & 0.97 & $0 \sim 4 \mathrm{~h}$ \\
\hline & Day 3 & ZT16 ZT20 & $14.51 / 6.61^{*}$ & 0.74 & $4 \sim 8 \mathrm{~h}$ \\
\hline & Day 5 & ZT0 & $121.6 / 6.61^{*}$ & 0.96 & $12 \mathrm{~h}$ \\
\hline & Day7 & ZT0 & $46.9 / 6.61^{*}$ & 0.90 & $12 \mathrm{~h}$ \\
\hline \multirow[t]{5}{*}{ Cryl } & Control & ZT12 & $14.5 / 6.61^{*}$ & 0.74 & $0 \mathrm{~h}$ \\
\hline & Day 1 & ZT8 ZT12 & $142.24 / 6.61^{*}$ & 0.97 & $0 \sim 4 \mathrm{~h}$ \\
\hline & Day 3 & ZT12 ZT16 & $14.45 / 6.61^{*}$ & 0.74 & $0 \sim 4 \mathrm{~h}$ \\
\hline & Day 5 & ZT20 & $45.96 / 6.61 *$ & 0.90 & $8 \mathrm{~h}$ \\
\hline & Day 7 & ZT0 & $46.98 / 6.61^{*}$ & 0.90 & $12 \mathrm{~h}$ \\
\hline \multirow[t]{5}{*}{ Decl } & Control & ZT20 & $39.85 / 6.61 *$ & 0.89 & $0 \mathrm{~h}$ \\
\hline & Day 1 & ZT0 & $31.54 / 6.61^{*}$ & 0.86 & $4 \mathrm{~h}$ \\
\hline & Day 3 & ZT0 ZT4 & $13.01 / 6.61^{*}$ & 0.72 & $4 \sim 8 \mathrm{~h}$ \\
\hline & Day 5 & ZT8 & $54.84 / 6.61^{*}$ & 0.92 & $12 \mathrm{~h}$ \\
\hline & Day 7 & ZT8 & $85.98 / 6.61^{*}$ & 0.95 & $12 \mathrm{~h}$ \\
\hline
\end{tabular}

*Statistical significance of the cosine fit was considered when $\mathrm{F}$ was more than $\mathrm{F}_{0.05}\left(\mathrm{~F}>\mathrm{F}_{0.05}\right)$. Acrophase time was considered when the mRNA level at a given time-point was within $95 \%$ confidence bounds of the acrophase. The value $\mathrm{R}^{2}$ quantified significance of the fit. Phase shift was the time lag between the acrophase time in the control condition and that in resetting days. ns, no significant $24-\mathrm{h}$ rhythm.

different clock genes in the circadian re-entrainment. The light-induced acute expression of Per1 and Per2 most probably plays an important role in the resetting of the SCN clock (Albrecht et al. 1997, Liu et al. 1997, Shigeyoshi et al. 1997), because light-dependent phaseadvance or delay of the clock is impaired in mice deficient in Per1 and Per2 (Albrecht et al. 2001). In the present study, Per1 and Per 2 were rapidly reset within 3 days, while the other four clock genes Bmall, Cryl, Decl and Rev-erb $\alpha$ were not completely re-entrained until day 5 in the liver clock (Table 2). This observation suggested that Per 1 and Per2 may also be important in initiating the circadian resetting of the liver clock, which was consistent with the observation in the adrenal gland (Ishida et al. 2005). The relative slow resetting of Bmall, Cryl, Decl and Rev-erb $\alpha$ might result from a shift in the circadian feedback loops. In contrast, the time course of Per 1 and Per 2 were as similar as the other examined clock genes in the heart clock, which were mostly reset within 5 days (Table 4). This result suggested that the resetting mechanisms of the liver and heart clocks may be distinct. Moreover, Per1 and Per 2 were considered to be 
sensitive to external time cues. Recently, a lack of food anticipation is specifically associated with a mutation of Per2, demonstrating the critical involvement of this gene in receiving the feeding stimulus (Feillet et al. 2006). In the present study, only the liver clock was directly stimulated by the food cue, suggesting that the rapid resetting of Per 1 and Per2 may be induced by the feeding stimulus. Further studies on the feeding-induced rapid resetting of the circadian clock in the liver may be useful to give an appropriate interpretation.

We found that the resetting processes of clock genes in the liver and heart after the feeding and LD reversal via a light period transition in the present study were different from that via a dark period transition in our previous studies (Wu et al. 2008b). In the liver clock, Bmall, Perl, Cryl and Decl were almost reset within 2 days after the LD reversal via a dark period transition, but they needed 3-5 days to completely reverse their circadian phases via a light period transition (Table 2). Similarly, these four clock genes displayed relatively rapid phase shift rates by completing their circadian resetting within 3-5 days in the heart after the LD reversal via a dark period transition. In the present study, 5-7 days were needed for these genes to be completely re-entrained in the heart (Table 4). Thus, the resetting processes of clock genes in the liver and heart are obviously lengthened after the phase shift of feeding schedule and LD cycle via a light period transition compared to a dark period transition, which is consistent with our previous reports in the pineal gland (Wu et al. 2009). The mechanism by which the peripheral clocks differently responded to the LD reversal via a light or dark period transition is currently unknown. The different feeding and lighting regime in the transition period may be an important inducement. When the LD reversal was accomplished via a dark period transition, the food cue stimulated the animals as soon as the LD was reversed. However, when the LD reversal was accomplished via a light period transition, the food cue affected the animals $12 \mathrm{~h}$ after the LD reversion. Therefore, the simultaneous stimulus of light and food cues might be more effective to entrain the circadian rhythm of peripheral clocks.

In conclusion, the resetting processes of clock genes in the liver and heart were characterized with tissue- and gene-specific phase shift rates and resetting sequences. The examined clock genes were more rapidly reset in the liver than that in the heart. The rapid reentrainment of Per1 and Per2 in the liver suggested the important role of these two clock genes in initiating the circadian resetting of this clock. Moreover, our findings indicated that the re-entrainment of the liver and heart clocks were obviously lengthened after the phase shift of LD cycle via a light period transition compared to a dark period transition, which may provide new knowledge to reduce the symptoms of jet lag.

\section{Conflict of Interest}

There is no conflict of interest.

\section{Acknowledgements}

This work was supported by a grant from the Program for Changjiang Scholars and Innovative Research Teams in University (No. IRT 0653), the National Natural Science Foundation of China (No. 30970364), the Natural Science Foundation of Zhejiang Province, China (No. Y3090563).

\section{References}

ALBRECHT U, SUN ZS, EICHELE G, LEE CC: A differential response of two putative mammalian circadian regulators, mper1 and mper2, to light. Cell 91: 1055-1064, 1997.

ALBRECHT U, ZHENG B, LARKIN D, SUN ZS, LEE CC: mPer1 and mPer2 are essential for normal resetting of the circadian clock. J Biol Rhythms 16: 100-104, 2001.

BARRETT RK, TAKAHASHI JS: Temperature compensation and temperature entrainment of the chick pineal cell circadian clock. J Neurosci 15: 5681-5692, 1995.

DAMIOLA F, LE MINH N, PREITNER N, KORNMANN B, FLEURY-OLELA F, SCHIBLER U: Restricted feeding uncouples circadian oscillators in peripheral tissues from the central pacemaker in the suprachiasmatic nucleus. Genes Dev 14: 2950-2961, 2000.

DONG Y, WU T, NI Y, KATO H, FU Z: Effect of fasting on the peripheral circadian gene expression in rats. Biol Rhythm Res 41: 41-47, 2009.

DUNLAP JC: Molecular bases for circadian clocks. Cell 96: 271-290, 1999. 
FEILLET CA, RIPPERGER JA, MAGNONE MC, DULLOO A, ALBRECHT U, CHALLET E: Lack of food anticipation in Per2 mutant mice. Curr Biol 16: 2016-2022, 2006.

GREEN CB, TAKAHASHI JS, BASS J: The meter of metabolism. Cell 134: 728-742, 2008.

HARA R, WAN K, WAKAMATSU H, AIDA R, MORIYA T, AKIYAMA M, SHIBATA S: Restricted feeding entrains liver clock without participation of the suprachiasmatic nucleus. Genes Cells 6: 269-278, 2001.

HASTINGS MH: Circadian clocks. Curr Biol 7: R670-R672, 1997.

ILLNEROVÁ H, VANĚČEK J, HOFFMANN K: Adjustment of the rat pineal N-acetyltransferase rhythm to eight-hour shifts of the light-dark cycle: advance of the cycle disturbs the rhythm more than delay. Brain Res 417: 167$171,1987$.

ISHIDA A, MUTOH T, UEYAMA T, BANDO H, MASUBUCHI S, NAKAHARA D, TSUJIMOTO G, OKAMURA H: Light activates the adrenal gland: timing of gene expression and glucocorticoid release. Cell Metab 2: 297$307,2005$.

LIU C, WEAVER DR, JIN X, SHEARMAN LP, PIESCHL RL, GRIBKOFF VK, REPPERT SM: Molecular dissection of two distinct actions of melatonin on the suprachiasmatic circadian clock. Neuron 19: 91-102, 1997.

LIVAK KJ, SCHMITTGEN TD: Analysis of relative gene expression data using real-time quantitative PCR and the $2^{-\Delta \Delta \mathrm{Ct}}$ method. Methods 25: 402-408, 2001.

MIRANDA-ANAYA M, BARTELL PA, YAMAZAKI S, MENAKER M: Circadian rhythm of ERG in Iguana iguana: role of the pineal. J Biol Rhythms 15: 163-171, 2000.

REDDY AB, FIELD MD, MAYWOOD ES, HASTINGS MH: Differential resynchronisation of circadian clock gene expression within the suprachiasmatic nuclei of mice subjected to experimental jet lag. $J$ Neurosci 22: 73267330, 2002.

SHIGEYOSHI Y, TAGUCHI K, YAMAMOTO S, TKEKIDA S, YAN L, TEI H, MORIYA T, SHIBATA S, LOROS JJ, DUNLAP JC, OKAMURA H: Light-induced resetting of a mammalian circadian clock is associated with rapid induction of the mPer1 transcript. Cell 91: 1043-1053, 1997.

STOKKAN KA, YAMAZAKI S, TEI H, SAKAKI Y, MENAKER M: Entrainment of the circadian clock in the liver by feeding. Science 291: 490-493, 2001.

SUJINO M, NAGANO M, FUJIOKA A, SHIGEYOSHI Y, INOUYE ST: Temporal profile of circadian clock gene expression in a transplanted suprachiasmatic nucleus and peripheral tissues. Eur J Neurosci 26: 2731-2738, 2007.

TAKAMURE M, MURAKAMI N, TAKAHASHI K, KURODA H, ETOH T: Rapid reentrainment of the circadian clock itself, but not the measurable activity rhythms to a new light-dark cycle in the rat. Physiol Behav 50: 443449, 1991.

WAKAMATSU H, YOSHINOBU Y, AIDA R, MORIYA T, AKIYAMA M, SHIBATA S: Restricted-feeding-induced anticipatory activity rhythm is associated with a phase-shift of the expression of mPer1 and mPer2 mRNA in the cerebral cortex and hippocampus but not in the suprachiasmatic nucleus of mice. Eur J Neurosci 13: 11901196, 2001.

WU T, JIN Y, KATO H, FU Z: Light and food signals cooperate to entrain the rat pineal circadian system. $J$ Neurosci Res 86: 3246-3255, 2008a.

WU T, JIN Y, NI Y, ZHANG D, KATO H, FU Z: Effects of light cues on re-entrainment of the food-dominated peripheral clocks in mammals. Gene 419: 27-34, 2008b.

WU T, DONG Y, YANG Z, KATO H, NI Y, FU Z: Differential resetting process of circadian system in rat pineal gland after the reversal of light/dark cycle via a 24-h light or dark period transition. Chronobiol Int 26: 793$807,2009$. 